\title{
O DELÍRIO DA SOLIDÃO SOBRE O ASSASSÍNIO E O FRACASSO ORIGINAL
}

\author{
Ricardo Timm de Souza*
}

SINTESE - Neste artigo, o autor intenta caracterizar de que forma o fato de um assassinato real se constitui em um fracasso definitivo em dois diferentes sentidos: no que tange à impossibilidade do assassino de romper a autocompreensão de sua solidão no sentido de uma relação ética com outrem (a impossibilidade de aceitação da alteridade do Outro, em sentido levinasiano), e no que diz respeito ao fato de que o assassino não consegue anular aquilo que se propõe: a alteridade do outro propriamente dita.

PALAVRAS-CHAVE - Solidão. Fracasso. Alteridade. Relações éticas.
ABSTRACT - The author intends to analyze to which extent the fact of a real murder must be regarded as a definitive failure in two different senses. First, it means the impossibility of the murderer's breaking off his solitude's selfunderstanding insofar as an ethical relation to the other is concerned (the impossibility of the acceptance of the Other's alterity, in the Levinasian sense). Secondly, it refers to the impossibility for the murderer to annihilate the very alterity of the Other.

KEY WORDS - Solitude. Failure. Alterity. Ethical relations.

\section{Como introdução: no extremo}

"Mas se não há-de falar nunca do assassinato de um homem como de uma figura, nem mesmo de uma figura exemplar em uma lógica do emblema, uma retórica da bandeira ou do martírio. A vida de um homem, única assim como sua morte, será sempre mais do que um paradigma e outra coisa que não um simbolo. E é isto mesmo que um nome próprio sempre deveria nomear" (J. Derrida). ${ }^{1}$

Em um de seus livros, conta-nos Elie Wiesel a seguinte história:

“[...] O Oberkapo do 52. Kommando era um holandês: um gigante de mais de dois metros de altura. Setecentos prisioneiros trabalhavam sob suas ordens e gostavam dele como de um irmão. Ninguém havia sofrido uma agressão de sua parte, nem ouvido uma maldição de sua boca.

Ele tinha sob seu serviço um jovem criado, um Pipel, como era chamado, uma criança com os traços do rosto bem desenhados, que não se adequava ao nosso campo de concentração [...].

* Doutor. Professor do Curso de Pós-Graduação em Filosofia da Pontificia Universidade Católica do Rio Grande do Sul (PuCRS).

1 Espectros de Marx. Rio de Janeiro: Relume Dumará, 1994, p. 7. 
Um dia voou pelos ares a estação elétrica de Buna. Chamada a Gestapo, concluiu esta por sabotagem. Localizou-se uma pista que conduzia ao bloco do Oberkapo holandês. Lá foi descoberta uma considerável quantidade de armas.

O Oberkapo foi preso. Torturado em vão ao longo de várias semanas, não forneceu nenhum nome. Foi enviado para Auschwitz e lá desapareceu.

Mas seu ajudante permaneceu em nosso campo de concentração, na prisão. Igualmente torturado, permaneceu ele também calado. A SS condenou-o, juntamente com dois outros prisioneiros que haviam sido encontrados com armas, à morte.

Certo dia, ao voltar do trabalho, vimos, montadas na praça principal do campo, três forcas. Ao redor, os SS com ameaçadoras armas, a cerimônia normal. Três candidatos à morte, entre os quais o pequeno Pipel, o anjo de olhos tristes.

Os SS pareciam preocupados, mais inquietos que de costume. Enforcar uma criança na frente de milhares de espectadores não era coisa de pouca monta. O chefe do campo leu a sentença. Todos os olhos estavam dirigidos ao menino. Ele estava cor de cinzas, mas quase quieto, e mordia os lábios. A sombra da forca cobria-o completamente.

Desta vez, o Lagerkapo negou-se a servir de carrasco. Três SS ocuparam esta posição.

Os três condenados subiram simultaneamente sobre suas cadeiras. Três pescoços foram envolvidos simultaneamente pelas cordas da forca.

'Viva a liberdade!'- gritaram os dois adultos.

O menino permaneceu calado.

'Onde está Deus, onde está ele?', perguntou alguém atrás de mim.

A um sinal do Lagerchef foram as cadeiras retiradas.

Fez-se absoluto silêncio em todo o campo. No horizonte, o sol se punha.

'Retirar bonés!'- gritou o Lagerchef. Sua voz soou baixa. Nós chorávamos.

'Colocar bonés!'

Começou então a marcha diante dos executados. Os dois adultos não mais viviam. Suas línguas azuladas pendiam fora da boca. Mas a terceira corda não pendia imóvel: o leve menino ainda vivia...

Mais de meia hora ficou ele lá pendurado e lutou, frente aos nossos olhos, entre vida e morte. E nós tínhamos de olhá-lo no rosto. Ele vivia ainda, quando passei por ele. Sua língua ainda estava vermelha, seus olhos ainda não estavam apagados.

Atrás de mim ouço o mesmo homem perguntar:

'Onde está Deus?'

E ouvi uma voz atrás de mim responder:

'Lá - lá está ele, na forca'.

Nesta noite, a sopa teve gosto de cadáver."2

\section{A insuficiência da descrição fenomenológica e da aproximação hermenêutica}

O fato "puro" de um assassinato perpetrado conduz a fenomenologia descritiva incisiva e dolorosamente até seus limites. Se a descrição fenomenológica do acontecido for perfeita, igualmente perfeita será seu acabamento, que consistirá, exatamente, em encontrar-se consigo mesma, com suas intenções filosóficas, ao

2 WIESEL. Elie. "Die Nacht zu begraben, Elisha" - Sonderausgabe aus Anlass der Verleihung des Nobelfriedenspreises 1986, Bechtle Verlag (tradução nossa). 
fim de seu trajeto, reiterando sua vocação e reafirmando sua habilidade original. Pois as sobras e circunstâncias de um tal acontecimento - aquilo que ainda poderia restar ao processo de descrição - pertencem tão pouco ao essencial do fato consumado quanto uma descrição de tal fato por um espectador casual a curta distância. Há um excesso de concentração no acontecido, um excesso e um peso que o discurso não acompanha. A descrição pode ser perfeita - e, quanto mais perfeita for, mais insuficiente será; quanto mais dignos os procedimentos que utilize, mais distante permanecerá da coisa mesma. E não é pequeno sinal de seu refinamento o fato de não invadir - não poder fazê-lo - o essencial da questão. Uma descrição fenomenológica de um assassinato completa-se exatamente na medida em que o núcleo do factum permanece intocado.

Quanto à aproximação hermenêutica, sem dúvida contribuirá para que se possa distinguir de forma definitiva esse fato de todos os outros; suas camadas sucessivas postas a descoberto pelas dimensões interpretativas contribuirão para que o essencial retorne contínua e precisamente à sua posição central, essencial, ao seu estatuto de essencialidade irredutivel, onde essencial significa, aqui: primeiro, original, primigênio. Trata-se do fato que se intenta interpretar, mas, antes de ser interpretado, trata-se de um fato real, de um factum, ou seja, um dado que se inscreve de uma vez para sempre na ordem dos acontecimentos acontecidos e, portanto, origem de toda possibilidade de interpretação, irrepetível e irrevogável em sua unicidade e particularidade. Nenhuma interpretação se lhe pode substituir; se 0 fizesse, estaria se substituindo à raiz da própria possibilidade de interpretação, ou seja, negando-se a si mesma.

Tanto a descrição fenomenológica como a aproximação hermenêutica provam aqui, em suas linhas gerais, sua validade: contribuem enfim para isolar o particular acontecimento do que é de certo modo inessencial embora importante: os antes e depois, as circun-stâncias, as ex-plicações, causas e conseqüências, julgamentos, justificativas e legitimações com seus contrários: não-justificativas e nãolegitimações. Ao fim e ao cabo, permanece o fato $n u$, sempre novo ainda que antigo, concentrado em si mesmo, em sua verdade não passível de ser suavizada - um dado que nenhum logos preenche ou esvazia de sentido, uma inscrição que, acontecida embora no decorrer do tempo, encrava-se na ordem da eternidade.

\section{Do fenômeno à metafenomenologia}

$\mathrm{E}$, não obstante, o acontecimento do assassinato clama sua condição de excepcionalidade no espectro dos fenômenos observáveis da realidade. Trata-se, em seu instante preciso, de uma severa detenção da roda do tempo, uma hesitação fundamental, a concentração extrema de um preciso instante em si mesmo, sem sucedâneos justificantes, afastado do horizonte dos acontecimentos lineares por uma descrição e uma interpretação filosóficas rigorosas que nele provam seus limites.

Mas por que "excepcionalidade"? Talvez porque, como no caso de outros acontecimentos-limite, abra-se aqui uma brecha na ordem onto-lógica. Nenhum dos conceitos maiores da filosofia permanece como era até então - liberdade e necessidade, ser, vida e morte, ética e ontologia, lógica e cosmologia, tudo tem de 
ser reescrito. O ser do assassinado reduzido à sua inércia definitiva, "pré-lógica"; a coisificação pré-racional do vivo (ainda que o ato tenha sido planejado com a mobilização do mais intenso ferramental racional); o logos do observador arrastado violentamente a seus limites, ao abismo que cerca a inelutabilidade que nenhuma vontade é capaz de anular: entre o ser e o logos abre-se violentamente um vácuo, um espaço sem anterioridades ou ligações perceptíveis com outros tempos e espaços, com outros mundos de significação mais suaves ou mais compreensíveis. Estamos frente à incompreensibilidade lógica radical, uma incompreensibilidade por definição, por mais que o logos reassuma imediatamente sua função de tentar neutralizar - ou seja, com-preender - o incompreensivel: será já tarde demais - o instante em questão é infinitamente curto, sua extensão racional é apenas sua condição de definitivo. Não há como matematizá-lo: ele é seu próprio universo e seu próprio parâmetro; é em si que se encontram suas referências possiveis.

Mas que universo é esse? Um uni-verso na verdadeira extensão da palavra, e um novum. Ali se desenrola um drama que não se conhece anteriormente com esta radicalidade: um drama de limites. Estamos, aí, exatamente, nesta insegurança radical em que se constituem estas fronteiras, estes limites, e a impossibilidade humana de deles escapar. Pois o assassinato é uma questão humana; por mais crueldade que se use, não se assassina um animal ou planta ao matá-los, nem um objeto ao destruí-lo.

E, a esses limites, nossa condição humana nos leva até eles. Há de ir além além de qualquer interpretação e descrição, de seguir em frente, apesar de tudo; há de se assumir os paradoxos que emergem da inquietação extrema dos limites no momento exato, indefinivel porém definitivo, em que acontecem. Há que tentar aprofundar eticamente o mergulho no vácuo que o preciso acontecimento único de um assassinato abre à nossa frente. $\mathrm{O}$ assassinato é uma questão ética por excelência, uma questão metafenomenológica, que envolve sempre muito mais do que um solitário perpetrador ou a descrição do ato perpetrado. Há ali a vítima; ainda que fale, é reduzida à posição de sem-voz e, portanto, de sem-logos, e, não obstante, é na vítima exatamente que o resultado final do ato se consubstancia. Se a descrição e a interpretação são dependentes dos acontecimentos onde, de algum modo, a vítima conservaria a palavra, ainda que em mero nível corroborativo ou negador, aqui, na precipitação metafenomenológica do instante inigualável, não há palavra de que lançar mão; a luta pela aniquilação da alteridade do Outro é uma luta eminentemente muda -e, por isso, sua violência é extrema. E a metafenomenologia é, em certa dimensão, a arte da aproximação, precária mas recorrente, de atos éticos, ainda que mudos, em seus limites, nas extremidades do próprio mundo. 


\section{A luta}

"O assassinato é a contradição no auge da violência. Nele a violência vai até ao absurdo e inverte-se em impotência. Nele se chocam e se 'provam' o poder ontológico e o poder ético" (L. C. Susin). ${ }^{3}$

\section{As bases}

O assassínio, como ato extremamente concreto, baseia-se sobre fatos também concretos ao extremo: é a radicalização da objetividade do acontecer. É necessário, para que ocorra, que uma série de dados "objetivos" se dêem; é sobre esses, a partir de sua articulação sob a forma de simultaneidade, que se constrói sua violência.

Qual é, agora, a condição primordial que pode dar origem a este ato extremo? Antes de tudo, a pluralidade - ninguém mata ninguém se estiver solitário em uma ilha deserta, e o suicídio pertence a uma esfera totalmente diferente de realidade, que não cumpre analisar aqui. Haverá, assim, no mínimo dois: o agente e o paciente do ato. $\mathrm{E}$ há a necessidade incontornável da não-neutralidade da relação: ninguém mata quem lhe é indiferente, a menos que esta indiferença assuma exatamente a forma de uma diferença que provoque, no assassino, a pulsão do ato extremo.

Mas algo mais - ou anterior - é necessário, a saber: que tanto agente quanto paciente estejam na posse de suas vidas: estejam vivos. Estar vivo para o agente significa ter a capacidade de organizar o seu ato e perpetrá-lo, ainda que tal se dê de forma simultânea. Para o paciente, estar vivo significa aqui, antes de tudo, ser humano, ou seja, ter alguma espessura própria, apresentar ao agente alguma face de ataque ou possibilidade de resistência real ontológica - como na guerra entre "iguais" - ou ética - como na guerra ou no combate entre desiguais.

Todavia, o instante do assassinato ${ }^{4}$ é sempre ético, pois significa, exatamente, que as resistências ontológicas foram vencidas - o adversário (já) está desar"mado, derribado, humilhado, desigual. É o instante da verdade, uma verdade que - ressaltemos ainda uma vez - se inscreve definitivamente na história. Sua única resistência que ainda persiste é aquela que advém exatamente de sua incapacidade de reagir de igual para igual. Só pode agir de diferente para igual. Não se trata, ou não se trata mais, de um jogo de iguais; a diferença imiscuiu-se definitivamente na situação. Trata-se de um cara-a-cara de diferentes e, precisamente por isso, de um frente-a-frente de gênero único, ético. A condição do agente pode ter passado do ter de se defender para não morrer à situação de poder escolher entre

3 SUSIN, Luiz Carlos. O homem messiânico - uma introduçăo ao pensamento de Emmanuel Levinas. Porto Alegre, Petrópolis: EST, Vozes, 1983, p. 133.

4 Não estamos ignorando o corolário de sofrimento que cerca uma questão extrema como é um assassinio; apenas queremos desenfocar nossa atenção desse aspecto, concentrando-a na situação quase esquemática do assassinato propriamente dito. A questão do sofrimento em geral mereceu nossa atenção enquanto problema filosófico no texto "Reflexões sobre a questão do sofrimento a partir de Emil Cioran e Emmanuel Levinas" (In: SOUZA, Ricardo Timm de. Totalidade \& desagregação - sobre as fronteiras do pensamento e suas alternativas. Porto Alegre: EDIPUCRS, 1996, p. 139150). 
matar ou não o oponente (lembremos das antigas lutas de gladiadores); o drama pode mesmo ter-se iniciado nessa segunda fase, quando, por exemplo, um adulto se coloca a questão se matará ou não uma criança indefesa. Em ambos os casos, a originariedade da questão é a assimetria que emerge da diferença de condições entre os participantes do drama; e é essa assimetria incontomável que conduz a questão indiscutivelmente ao estatuto ético. Só existe ética - e, por extensão, o seu "contrário" -, entre "plurais", e plurais definitivamente diferentes. E, se é o encontro entre diferentes que traduz o tempo propriamente humano, trata-se de uma inscrição definitiva de uma certa ordem de acontecimentos na ordem do tempo. Esta ordem não pode ser invertida ou reescrita de outra forma ou com outros atores: também ela é única, como único é o instante em que a verdade do assassinato se oferece à inteligibilidade que não pode negá-la. Nada fará com que o tempo volte atrás e o vietkong atingido na cabeça pelo oficial sul-vietnamita na conhecida cena real da guerra do Vietnã - levante-se e inverta os papéis daquele acontecimento marcante e definitivo em que se constitui seu assassinato frente às câmaras. Como tudo o que é humano, trata-se de um acontecimento absolutamente único, e não há força capaz de negá-lo nem sistema capaz de explicá-lo de forma a não sobrar nada - pois o "nada" em que se constitui o assassinado, exatamente por não se confundir com nada mais - não pode ser apagado do conjunto total de acontecimentos que preencheram a linha infinita de instantes que antecederam o preciso instante que agora vivemos.

\section{As condições}

Algumas condições são, agora, necessárias para que o assassino potencial cometa seu crime; ele deverá aproveitar-se da não-potência do outro para tentar reduzi-lo a "nada". E isso porque essa não-potência do outro, não-potência de ser (não ser, ou ser menos forte, hábil, armado...) não é "nada", mas "algo" - exatamente: Alteridade ética (caso contrário, não haveria a vontade de reduzir o Outro àquilo que, para a "cosmovisão ontológica", mais se assemelha ao Nada: a morte). E Alteridade ética irredutível à vontade de aniquilação do agente - do Mesmo que pretende anulá-la. É isso que conduz ao ato extremo: “[...] é o 'outro' que se assassina, aquele que se recusa à apropriação e totalização, o não neutralizável”. 5

Pois é exatamente isso que 0 assassino pretende: transformar absolutamente o Outro (o não neutro) em objeto de meu poder; anular a Alteridade do Outro absolutamente, enquanto visage (olhar ou rosto em sentido levinasiano): 6 aquilo que prova que o Outro, combalido em toda sua dignidade de ser, mantém intocada sua "condição de ser" Outro com relação a quem o observa ou que tem sobre ele o poder de vida e morte.

5 Op. cit., p. 134.

6 Em outro lugar destacamos a dificuldade de tradução desse importante termo levinasiano, caracterizando que, em nosso entender, "olhar" resiste mais claramente à objetivação do que "rosto", ainda que "rosto", nesse contexto, nāo se circunscreva à materialidade de alguma face (Cf. SOUZA, Ricardo Timm de Souza. Totalidade \& desagregaçạa..., p. 182, nota 327). A tradução portuguesa que ora utilizamos emprega o termo rosto por visage. 
Assim, "o rosto (visage) recusa-se à posse, aos meus poderes. Na sua epifania, na expressão, o sensível ainda captável transmuda-se em resistência total à apreensão. Essa mutação só é possivel pela abertura de uma dimensão nova. Com efeito, a resistência à apreensão não se verifica como uma resistência inultrapassável como dureza do rochedo contra a qual o esforço da mão se quebra, como o afastamento de uma estrela na imensidão do espaço"7 - como vimos, os poderes "normais" estão já definitivamente desequilibrados. "A expressão que o rosto introduz no mundo não desafia a fraqueza dos meus poderes, mas o meu poder de poder. $O$ rosto, ainda coisa entre as coisas, atravessa a forma que entretanto o delimita. O que quer dizer concretamente: o rosto fala-me e convida-me a uma relação sem paralelo com um poder que se exerce, quer seja fruição, quer seja conhecimento."8

Quando toda a racionalidade da força cessou com a vitória de um dos lados do agente - ou quando esta racionalidade nunca teve vez pelo desequilíbrio absoluto e desmedido das forças daqueles que configuram esse drama, é exatamente aí que a voz do fraco se faz ouvir; não uma voz física, mas uma voz ética, um convite à manutenção da pluralidade original, um convite a uma relação com a diferença, o que é, sempre, uma oferta de paz.

" $E$, no entanto, a nova dimensão abre-se na aparência sensível do rosto. A abertura permanente dos contornos da sua forma na expressão aprisiona numa caricatura essa abertura que faz explodir a forma. O rosto no limite da santidade e da caricatura oferece-se, portanto, ainda num sentido a poderes... O assassínio visa ainda um dado sensivel e, entretanto, encontra-se perante um dado cujo ser não poderá suspender-se por uma apropriação. Encontra-se perante um dado absolutamente não neutralizável."9 A oferta de paz e relação pode ser rejeitada, porque é apenas uma oferta, e pode ser violentamente negada: não se estabelece com a solidez neutra da pedra, mas é em sua "essência" não neutralizável - sua dimensão primordial é sua posição particular e inconfundivel frente ao potencial assassino. Uma posição que, por não indiferente, desata a contenção de forças do agente poderoso e pode instigar à vontade extrema de apropriação ou à compulsão patológica do extermínio enquanto negação - o assassinato.

Essa vontade extrema de apropriação diferencia-se substancialmente da lógica da apropriação dos seres e dos objetos que estejam sujeitos à vontade do forte. “A 'negação' efetuada pela apropriação e pelo uso mantinha-se sempre parcial. A tomada que contesta a independência da coisa conserva-a 'para mim'. Nem a destruição das coisas, nem a caça, nem o extermínio de seres vivos visam o rosto (visage), que não é do mundo. Revelam ainda trabalho, têm uma finalidade e respondem a uma necessidade." 10 Colho o fruto, caço o animal, em princípio, para me alimentar deles; derrubo a madeira para construir a casa; lavro o campo para arar; mas, em nenhum desses casos, enfrento-me com o tipo de assimetria que me coloca em uma posição de ser convidado a estabelecer relação, e relação éti-

7 LEVINAS, Emmanuel. Totalidade e infinito. Lisboa: Edições 70, 1988, p. 176 (doravante TI, seguido do número da página).

8 TI, 176.

9 TI, 177.

10 TI, 177. 
ca11 - pois a relação ética só se pode estabelecer entre alguém e o Outro "que não é do mundo", ou seja, que não pertence à ordem do apreensivel como ente a partir do manuseio ou do logos - aqui, funções de uma mesma potência neutralizante-objetivante. Literalmente, para além de qualquer fenomeno-logia, o Outro é "de outro mundo", onde a relação intencional não mantém sua validade porque não é suficiente para de alguma forma circunscrever o essencial de qualquer Alteridade: exatamente sua condição de Alteridade com relação a qualquer forma de objetivação. O olhar (visage) não se mostra nem se dá à intencionalidade. Procurando o olhar, vemos no máximo os "olhos", ou, procurando o rosto, vemos apenas a face; mas é o que não podemos ver que caracteriza o olhar ou rosto como de alguém que não somos nós. Ninguém circunscreve um olhar, e todas as representações figurativas deste não dão conta de sua realidade mais fundamental, ou seja, de sua palavra que olho algum capta, de seu sentido propriamente ético. Está fora - além - do âmbito dos poderes do agente, e por isso pode provocá-lo até ao extremo - e extrema é a situação de vida e morte.

\section{O exercício}

Em contraposição às negações dialéticas parciais pelas quais o ser humano constrói sua vida a partir da produção de seu alimento e da construção de sua casa, "(só) o assassínio aspira à negação total. A negação do trabalho e do uso, tal como a negação da representação, efetuam uma tomada ou uma compreensão, assentam na afirmação ou visam-na. Matar não é dominar mas aniquilar, renunciar em absoluto à compreensão"12 - a negação absoluta da paz que se instauraria se a oferta de encontro fosse aceita. Trata-se da mobilização de todo o poder possível por parte do criminoso: um poder que se inverte em loucura e impotência. "O assassínio exerce um poder sobre aquilo que escapa ao poder. Ainda poder, porque o rosto (visage) exprime-se no sensivel; mas já impotência, porque o rosto rasga o sensivel. A alteridade que se exprime no rosto fornece a única 'matéria' possível à negação total. Só posso querer matar um ente absolutamente independente, aquele que ultrapassa infinitamente os meus poderes e que desse modo não se opõe a isso, mas paralisa o próprio poder de poder. Outrem é o único ser que eu posso querer matar"13 - porque, definitivamente, não é "eu" e não me posso de nenhuma forma confundir com ele, como posso, em graus diversos de projeções e de delírio, confundir-me com o mundo que me cerca, apoiado que sou em minha tarefa de conquistar o mundo por um intelecto poderoso que, no dizer do filósofo antigo, "é de certa forma todas as coisas". Aqui, não se trata da questão de ser, mas, fundamentalmente, de não ser eu nem o conjunto de minhas potências, ou seja, de não ser neutro em relação a mim.

11 Falamos aqui, naturalmente, de forma inicial e esquemática; o quanto de "humano" está presente na realidade circundante, o quanto de oferta de paz é a mera existência de um outro ser, é questão que se desenvolve a partir da descoberta do fato ético primordial - o reconhecimento da Alteridade enquanto tal - e não previamente a esta descoberta. 0 que se pretende é destacar suficientemente a contraposição estabelecida desde a inefabilidade do olhar do outro, que em nenhum momento pode ser "objetivado".

13 TI, 177.

3 TI, 177 
"Mas em que é que a desproporção entre o infinito e os meus poderes difere da que separa um obstáculo muito grande de uma força que se aplica a ele? Seria inútil insistir na banalidade do assassínio, que revela a resistência quase nula do obstáculo. Esse incidente, o mais banal da história humana, corresponde a uma possibilidade excepcional - dado que aspira à negação total de um ser. Não diz respeito à força que esse ser pode possuir enquanto parte do mundo. Outrem, que pode soberanamente dizer-me não, oferece-se à ponta da espada ou à bala de revólver e toda a firmeza inabalável do seu 'para si' com o não intransigente que opõe, apaga-se pelo fato de a espada ou a bala terem tocado nos ventrículos ou nas aurículas de seu coração."14 Tudo indica que, uma vez esboçado o drama, este se desenrolará até o fim, com a morte do paciente que sofre 0 ato violento. Sua oposição eloqüente esbarra em sua materialidade, e ele já não é resistência considerável: acabará por ser traído por sua materialidade e desabará atingido pela desestruturação de suas entranhas e estruturas ontológicas. Trata-se do paradoxo de seu "poder sem poder", poder desafiar o assassino desde sua simples posição diferente, sem poder impedir a consumação de seu ato.

A origem desta contradição candente é que "na contextura do mundo, ele (a vítima, R.T.S.) não é quase nada. Mas pode opor-me uma luta, isto é, opor à força que $\mathrm{o}$ ataca, não uma força de resistência, mas a própria imprevisibilidade de sua reação. Opõe-me assim não uma força maior - uma energia avaliável e que se apresenta, por conseguinte, como se fizesse parte de um todo - mas a própria transcendência do seu ser em relação ao todo; não como um qualquer superlativo de potência, mas precisamente o infinito da sua transcendência."15

É de se destacar o uso que faz Levinas do termo infinito, que nada tem a ver com o conceito normalmente estudado na tradição filosófica, mas é, antes, o que se opõe desde si mesmo, eticamente, a uma totalidade de sentido em seu processo sintético-unificante de totalização - a condição irredutivelmente ética da Alteridade propriamente dita, insubsumível como dimensão de uma ordem que a englobe. O Infinito é a um tempo conteúdo inapreensível e a expressão da Alteridade: "Esse infinito, mais forte que o assassínio, resiste-nos já no seu rosto, é o seu rosto, é a expressão original, é a primeira palavra: "não cometerás assassínio"', 16 ou seja: preservarás minha integridade diferente da tua, apesar de toda a provocação que a minha mera existência possa significar para a tua totalidade, e apesar de todo o meu sentido que tu não compreendes mas com o qual podes vir a te relacionar. "O infinito paralisa o poder pela sua infinita resistência ao assassínio que, dura e intransponivel, brilha no rosto de outrem, na nudez total de seus olhos, sem defesa, na nudez da abertura absoluta do transcendente" 17 - transcendente à minha totalidade, às minhas possibilidades e a toda criatividade de meu jogo integrador do Diferente, autocompreensivo e destilador de suas próprias regras.

\footnotetext{
14 TI, 177.

15 TI, 177-178.

16 TI, 178.

17 TI, 178.
} 


\section{Limite e nascimento da liberdade}

É nesse momento que chegamos ao limite das possibilidades do assassinato. "Há uma relação, não com uma resistência muito grande, mas com alguma coisa de absolutamente Outro: a resistência do que não tem resistência - a resistência ética. A epifania do rosto (visage) suscita a possibilidade de medir o infinito da tentação do assassinio, não como uma tentação de destruição total, mas como impossibilidade - puramente ética - dessa tentação e tentativa."18

Qual é, então, a diferença entre uma resistência de oposição, real, e uma resistência de alteridade ao projeto de assassinato? "Se a resistência ao assassínio não fosse ética, mas real, teríamos uma percepção dela com tudo aquilo que na percepção redunda em subjetivo. Ficariamos no idealismo de uma consciência da luta e não em relação com Outrem, relação que pode transformar-se em luta, mas que já ultrapassa a consciência da luta. A epifania do rosto é ética. A luta de que o rosto pode ser a ameaça pressupõe a transcendência de expressão."19

Estamos agora em um momento extremamente delicado do discurso. Preparase a subversão de uma tradição milenar, aquela, pregada já por pensadores tão antigos como Heráclito, que afirma na luta a origem mais primeva da realidade: "O rosto ameaça de luta como de uma eventualidade, sem que tal ameaça esgote a epifania do infinito, sem que dela formule a primeira palavra. A guerra supõe a paz, a presença prévia não-alérgica de Outrem; não assinala o primeiro acontecimento do encontro." (grifo nosso.) ${ }^{20}$ A guerra supõe a antecedência da paz, não uma paz que meramente a prepare, mas a paz que se oferece enquanto possibilidade de manutenção da pluralidade original, ou seja, das diferenças originais e, a partir daí, proponha o acontecimento do encontro real (não neutro) entre os diferentes. Pois, contrariamente à consciência dos séculos e à "lógica" dos fatos, não pode haver guerra, se antes não se der a pluralidade primigênia de ao menos "dois diferentes" que podem a vir entrar em guerra - ou manter e promover a paz. No principio há a alternativa. Não pode haver assassinato, sem que antes, como destacamos ao início, não haja dois diferentes postos em uma posição, de alguma forma, "face-a-face". E aí, exatamente, repousa a anterioridade do face-aface com relação a tudo o que é humano - já que é neste esboço de encontro que o humano enquanto tal: o ético (ou seja, o propriamente humano) anterior à totalidade da guerra - pode vir a se definir como realidade determinante do futuro. Um futuro de paz que promete corroborar a impossibilidade de matar.

"A impossibilidade de matar não tem uma significação simplesmente negativa e formal; a relação com o infinito ou a idéia do infinito em nós condiciona-a positivamente" 21 - em outros termos, é possivel que percebamos em nós a incapacidade incontomável de abarcar o universo do diferente. "O infinito apresentase como rosto na resistência ética que paralisa os meus poderes e se levanta dura e absoluta do fundo dos olhos, sem defesa na sua nudez e na sua miséria. A compreensão dessa miséria e dessa fome instaura a própria proximidade do Outro."22

$18 \mathrm{TI}, 178$.

19 TI, 178.

$20 \mathrm{TI}, 178$.

21 TI, 178. Levinas refere-se ao modelo formal de Infinito de Descartes (Cf. TI, 175-176).

22 TI, 178. 
Mas esta apresentação da Alteridade não é formal, estática nem meramente figurativa; ela se dá como discurso original, fonte da linguagem, desneutralização do encontro. O discurso não surge por um capricho do logos solitário que organiza ạ realidade externa "em sua consciência" e expressa essa organização a quem quiser, ou puder, ouvir - mas origina-se exatamente antes que o logos se assenhore de sua solidão logocêntrica. "[...] é assim que a epifania do infinito é expressão e discurso. A essência original da expressão e do discurso não reside na informação que eles forneceriam sobre um mundo interior e escondido. Na expressão, um ser apresenta-se a si mesmo. O ser que se manifesta assiste à sua própria manifestação e, por conseguinte, apela para mim. Essa assistência não é o neutro de uma imagem, mas uma solicitação que me envolve a partir da miséria de sua Aitura. Falar-me é transpor a todo o momento o que há de necessariamente plástico na manifestação. Manifestar-se como rosto é impor-se para além da forma, é apresentar-se de uma maneira irredutível à manifestação, como a própria retidão do frente a frente, sem mediação de nenhuma imagem na sua nudez, ou seja, na sua miséria e na sua fome."23

A linguagem original não é a das palavras. 0 "encontro original" entre os diferentes transmuta assim uma outra crença como que intocada da tradição: a de que os "bons" conceitos - ser, logos, etc. - são neutros em sua origem, e, exatamente por isso, são bons. Não há conceito neutro, pois todos advêm da situação não neutra pré-original que se estabelece quando dois diferentes se encontram $e$ podem - ou não - vir a estabelecer um "discurso" "decorrente" daí, intersubjetivo. O discurso original, como a compreensão ou construção da verdade e como tudo o que pertence à esfera do humano, não é solitário em sua origem. Ele não se estabelece entre iguais, mas entre desiguais, porque ele deriva de uma situação infinitamente complexa, um encontro desde posições diversas e irredutiveis uma à outra. Quem não tem posição própria, ou seja, quem não está em uma situação em que sua alteridade - sua dignidade - esteja realmente preservada, não tem, também, condições de estabelecer discurso nenhum; suas tentativas recairão no vale comum de meros ecos do logos dominante, que é muito mais do que suas palavras e sua boa vontade eventual. E por aí percebe-se claramente o perigo mortal que ronda as boas intenções das chamadas "éticas do discurso". Toda ética do discurso só terá espaço, caso parta não de uma mesa-redonda ou da eqüidistância dos participantes, mas da assimetria radical dos participantes, e não de sua convertibilidade mútua ou de sua mútua decodificação. Há muito mais tensão na linguagem original, aquela que se instaura entre os radicalmente diferentes: ali já está o sentido em oferecimento pleno. Ou ela - a ética do discurso - indica inelutavelmente a sua própria superação na ação ética, ou se autodestruir wittgensteinianamente no artificial de alguma espécie de neutralidade, por sedutoramente construída que esta seja: pulveriza-se em suas próprias intenções, como acontece provavelmente com o estruturalismo em relação à idéia de sujeito tradicional.

23 TI, 178-179. 
E essa expressão nada leva consigo de irracional ou de numinoso - “[... não irradia como um esplendor que se espalha apesar do desconhecimento do ser irradiante [...] Manifestar-se assistindo à sua manifestação equivale a invocar 0 interlocutor e a expor-se à sua resposta e à sua pergunta. A expressão não se impõe nem como uma expressão verdadeira, nem como um ato. O ser oferecido na representação verdadeira continua a ser possibilidade de aparência [...] O ser que se exprime impõe-se, mas precisamente apelando para mim da sua miséria e da sua nudez - da sua fome de vida - sem que eu possa ser surdo a seu apelo. De maneira que, na expressão, o ser que se impõe não limita, mas promove a minha liberdade, suscitando a minha bondade. A ordem da responsabilidade ou a gravidade do ser inelutável gela todo o riso, é também a ordem em que a liberdade é inelutavelmente invocada de modo que o peso irremissivel do ser faz surgir a minha liberdade. O inelutável não tem a inumanidade do fatal, mas a seriedade severa da bondade." (Grifo nosso.) ${ }^{24}$

Estamos portanto às voltas com um fato deveras notável: a necessidade ética de responder à fome de outrem, ou à sua expressão "não me matarás!" tem origem não em uma imposição "natural" de alguma lei não nascida e imutável na ordem do cosmo, mas, sim, no fato original e definitivamente humano que me coloca face a face com outrem, e que me dá a oportunidade de, em respondendo a essa necessidade imperativa, fundar a legitimação ética de minha liberdade - e liberdade, aqui, só pode ser liberdade de não ser indiferente. A antiquíssima questão da mútua exclusão entre necessidade e liberdade toma aqui pois contornos novos - é necessário que a necessidade seja radical - uma questão de fome, de vida e de morte - para que a liberdade seja radical: a resposta ética a essa questão. ${ }^{25}$ Naturalmente, permanece a possibilidade de responder ou não ao apelo; mas o não responder significa o assumir de um modelo de liberdade que não leva em conta o que de radical habita o encontro; reduz-se à sua própria concha e se define como um modelo de atitude livre ao mesmo tempo fraca, porque eticamente intocada, e solitária, ou seja, não humana, por mais racionalizações e projeções que construa ao redor do núcleo de sua vontade, e por mais que se desdobre em racionalidades auto-referentes. O "não", possibilidade real de uma ação humana, nega, quando de seu exercício, a humanidade dessa ação e reduz, no fundo, o humano à sua caricatura, ou seja, a uma mônada isolada, sem relação com o outro: uma impossibilidade radical que indica, quando desdobrada no tempo, uma atitude não impossivel, mas intrinsecamente suicida. A negação do encontro ético é a forma mais trágica e definitiva de abdicação do humano, e sua radicalização material, o assassinato, o protótipo de todo o fracasso: quis anular a Alteridade do Outro e conquistei apenas um cadáver inerme.

24 TI, 179

25 Sobre a idéia de uma "liberdade investida" em Levinas, ver nosso ensaio "Traumatismo e Infinito" (In: SOUZA, Ricardo Timm de. Totalidade \& desagregação..., op. cit., p. 195 seg.). 


\section{Pensamento e linguagem}

Eis que penetramos assim no núcleo da expressão e da responsabilidade - ou melhor, da expressão que só pode ser completamente compreendida sob o aspecto da responsabilidade pelo que não sou eu. "O elo entre a expressão e a responsabilidade - condição ou essência ética da linguagem - essa função da linguagem anterior a todo o desvelamento do ser e ao seu frio esplendor permitem subtrair a linguagem à sua sujeição relativamente a um pensamento preexistente, cujos movimentos interiores ela teria unicamente a servil função de traduzir cá para fora ou de universalizar. A apresentação do ser no rosto não é verdadeira, porque $o$ verdadeiro refere-se ao não-verdadeiro, seu eterno contemporâneo, $e$ encontra inevitavelmente o sorriso e o silêncio do céptico. A apresentação do ser no rosto não deixa lugar lógico à sua contraditória. Por isso, no discurso que a epifania abre como rosto, não posso furtar-me pelo silêncio, como tenta Trasímaco irritado, no primeiro livro da República (sem de resto o conseguir). "Deixar homens sem comida - é uma falta que nenhuma circunstância atenua; a ela não se aplica a distinção do voluntário e do involuntário', diz Rabbi Yochanan. Perante a fome dos homens a responsabilidade só se mede 'objetivamente'. É irrecusável."26

Eis que a origem da linguagem não é o pensamento, nem a do pensamento a linguagem como articulação ordenada de signos lógicos (nenhum signo tem sentido senão para alguém que nele percebe o traço de uma comunicação que não surge por geração espontânea, mas pela possibilidade da comunicabilidade de algo por alguém); mas a origem da linguagem ordenada $e$ do pensamento é a expressão original de Alteridade que antecede qualquer processo de interiorização e questiona desde seu princípio a noção de con-sciência; antes de tomar intelectualmente ciência de algo, sou atingido por uma exigência que vem de muito além de minha interioridade; é o acontecimento traumático original do encontro que tentamos analisar em outro lugar ${ }^{27}$ e que remete à noção de "consciência passiva", "não intencional". ${ }^{28} 0$ encontro humano é a possibilidade da verdadeira inauguração do sentido humano (as referências sígnicas só têm sentido para alguém que, ao recebê-las, as rearticula em um todo de sentido - senão, não seriam nem ao menos interpretáveis) - "O rosto abre o discurso original, cuja primeira palavra é obrigação que nenhuma 'interioridade' permite evitar. Discurso que obriga a entrar no discurso, começo do discurso que o racionalismo exige com os seus votos, 'força' que convence mesmo 'as pessoas que não querem ouvir' (Platão) e fundamenta assim a verdadeira universalidade da razão... Ao desvelamento do ser em geral, como base do conhecimento e como sentido de ser, preexiste a relação com o ente que se exprime; no plano da ontologia, o plano ético."29

26 TI, 179.

27 Cf. SOUZA, Ricardo Timm. Traumatismo e Infinito (In: Totalidade \& desagregação..., op. cit., p. 179-198.

28 Cf. LEVINAS, E. A consciência não-intencional (In: LEVINAS, E. Entre nós - ensaios sobre a alteridade. Petrópolis: Vozes, 1997, p. 165-177).

29 TI, 179-180. 


\section{O assassinato como negação a priori da origem e mergulho no absurdo}

Dessa forma, o encontro ético com alguém não significa "sair de sua própria interioridade" para dedicar-se a outrem: significa expressar a crença, inclusive, na própria humanidade, na sua humanidade própria e mais profunda. A expressão de outrem enquanto exigência ética de resposta é a única forma de romper a totalização ontológica, ou seja, a solidão dolorosa de ser, da qual o século xx se dá conta com particular incisividade e que não é mais do que a expressão desenvolvida e culminância de todo um complexo movimento civilizatório que nega a realidade do Diferente, a não ser para subsumi-lo em seu próprio roldão energético. ${ }^{30}$

Voltemos, agora, aos inícios desta reflexão. O que significa, então, nesse contexto, o ato de assassinar alguém? Provavelmente, a radicalização desse instinto de morte em solo ou em conjunto, pela negação a priori da possibilidade de qualquer encontro, ou seja, de qualquer origem, e a permanência no indiferenciado da poeira cósmica. Assassinar não significa tirar a vida de um corpo - significa, antes, tentar tirar de todo um mundo de sentido a sua sustentação, como se essa, imanentemente, ali fosse alcançável; em outros termos, como se a Alteridade de outrem fosse alcançável e aniquilável pelo aniquilar de seu infinitamente precário substrato ontológico. Em que consiste o absurdo do assassinato? Consiste em que o assassino quer de sua vítima a única coisa que dela não pode conquistar: sua condição de Alteridade viva. Pois o assassino pode ter, ao fim e ao cabo, despojos a seus pés - um corpo inanimado ou mesmo destroçado, ou mesmo corpo nenhum, indiferenciado ou volatilizado que foi por uma incineração ou explosão atômica; pode ter uma prova (de resto inútil, pois nunca esteve realmente em questão) de sua potência ontológica; pode ter sua solidão só para si, o que significa, em último sentido, o direito de morrer sozinho, pode afogar-se em sua violência e proclamar o sem-sentido. Só não pode inverter a roda do tempo e seqüestrar a Alteridade ali onde ela habita, o instante único que foi a possibilidade do encontro que nunca se deu. $\mathrm{O}$ assassino quer a vida do Outro, mas só conquista a Morte, um corpo morto; a vida do outro - sua alteridade - refugiou-se no pesadelo de toda ontologia: no Nada, Nada de Ser.

\section{Síntese}

Revisemos o essencial do até aqui exposto. O Outro enquanto alteridade real é a possibilidade do rompimento de minha totalização, ou seja, de minha solidão de ser, ao constituir-se em expressão e oferta de paz original: fundamento da ética na qual a racionalidade se pode legitimar. Minha solidão pode, porém, escolher a morte da origem, ou seja, a negação da alteridade enquanto tal - pois a oferta é essencialmente apenas isso: oferta, e não coerção de nenhum tipo, muito menos necessidade lógica ou ontológica. E uma tal oferta oferta-se seguramente à simples negação.

30 Cf. SOUZA, Ricardo Timm de. O século XX e a desagregação da Totalidade (In: Totalidade \& desagregação..., op. cit., p. 15-29). 
Essa negação, porém, não é uma possibilidade ética, mas meramente ontológica, que expressa as contradições do ser envolto em sua própria inescapabilidade e desembocando então no absurdo das contradições insolúveis que emanam de sua solidão raivosa. Por quê? Porque "matar... é tentar o impossível e cair nas contradições do ódio... há no ódio do assassino o secreto desejo de 'objetivação' do outro para totalizá-lo. Mas objetivação 'do outro', não simplesmente de um cadáver, o que inclui a tentativa de torná-lo um objeto a seus próprios olhos, de tal forma que o outro possa testemunhar sua derrota e a destruição de sua transcendência, a sua objetivação e totalização no reino vitorioso do assassino. Por isso, o 'prazer' do assassino é matar o outro diante do outro mesmo: quer o outro como objeto e como sujeito que veja a humilhação da própria reificação, quer a contradição do outro morto e vivo." 31

Chegamos assim ao coração da contradição, na plástica descrição de L. C. Susin: "Seria então necessário matá-lo vivo. É possivel retê-lo no instante anterior ao golpe que determinará sua total objetivaçăo, matar lentamente - até por anos a fio - e submeter à destruição através do sofrimento sem desferir o último golpe. Este é o caráter absurdo do ódio: quer satisfazer-se, mas mantém o estado de insatisfação para poder se satisfazer... Mas... quando a objetivação está por chegar à sua plenitude, a vítima se retira deixando o assassino solitário com sua vitória... O outro revela, assim, na sua retirada, a infinitude do seu poder ético subtraindo-se ao poder ontológico do assassino, mostrando assim a fraqueza e a impotência deste, paralisando-o na insatisfação: é impossível que o outro veja sua objetivação. Há então uma inversão: o poder do assassino é daí por diante impotente para ir mais longe e tomar o outro que se retirou para além da morte, resguardado no mistério da transcendentalidade mesma que o assassino queria esmagar. 0 poder ontológico, espontâneo e sem justificações revela-se afinal sem fundamentos e uma fraqueza, poder sem poder" 32 - o fracasso original.

\section{Conclusão}

O momento único que representa para alguém o encontro com a Alteridade representa uma situação de fundamentos e de origem, uma oportunidade única pois toda oportunidade humana é, por definição, única: situação em que os seus próprios fundamentos estão expostos em sua precariedade solitária e convidados a se legitimarem pelo assumir de seu próprio sentido não tautológico; e origem potencial, onde uma história pode ser escrita e um tempo vazio pode ser preenchido pelo assumir de um instante de inauguração da ética, ou seja, da manutenção e promoção da pluralidade dos sentidos.

$\mathrm{O}$ assassinato em todas as suas infinitas modalidades - inclusive aquelas mais lentas e imperceptíveis, que não analisamos aqui - representa a mais radical negação unilateral dessa oferta de sentido, porque sem volta na ordem dos fatos e

31 SUSIN, Luiz Carlos. O homem messiânico..., op. cit., p. 135.

32 Op. cit., p. 136. 
autofágico em sua paixão patológica pelo sentido único: o do assassino. Mas o sentido único representa o aborto da linguagem e do pensamento, da liberdade e da necessidade, do próprio mundo e do tempo que transcende sua medição, da convivência e da relação de qualquer tipo - em suma, de tudo o que faz a humanidade do humano; e, portanto, todo assassinato é também um suicídio; 0 assassínio é definitiva e dolorosamente suicida e não escapa dos limites que grotescamente se auto-impõe: os de um definitivo fracasso original. 